\title{
Financial Sector Development and Economic Growth: The Case of Ghana (1980-2014)
}

\author{
Daniel Frimpong Yeboah $^{1 *} \quad$ George Amponsah Oppong ${ }^{2}$ \\ 1. Ministry of Finance, P.O.Box M40, Accra, Ghana \\ 2. Global Media Alliance, P.O. Box CT 5976, Cantonments-Accra, Ghana
}

This research is a build up on an academic thesis submitted by Mr. Daniel Frimpong Yeboah to obtain a Master of Arts Degree in Economic Policy Management at the University of Ghana, Legon, under the supervision of Professor Amoah Baah-Nuakoh.

Abstract

This paper examined the relationship between Financial Sector Development and Economic Growth in Ghana using an annual time series data from 1980-2014. The paper investigated empirically the impact of financial sector development on economic growth in Ghana using the Granger Causality Test, the Johansen Cointegration and the Error Correction Modeling (ECM) techniques. The intent of the framework used was to find out whether there exists a long-run relationship between growth and finance. The paper concluded that there exist a positive long run relationship between economic growth and financial sector development with financial sector developments Granger causing economic growth in Ghana. An enabling environment and financial sector interventions such as low interest rate that will enhance transfer of credit to the private sector must be pursued to enhance the economic development of Ghana.

Keywords: Financial Sector Development, Economic Growth, Financial System, Granger-Causality, Cointegration, Error Correction Modeling (ECM)

\section{INTRODUCTION}

\subsection{Background of the Study}

The finance services industry encompasses a broad range of organizations that deal with the management of money. In Ghana, the financial services industry is categorized into three main sectors:

- Banking and Finance (including Non-Bank Financial Services and

Forex Bureaus)

- Insurance and

- Financial markets/capital markets

The operating institutions include both foreign and local major banks, Rural and Community Banks (RCBs), Savings and Loans Companies (SLCs) and other finance and leasing companies.

Ghana's financial sector has undergone extensive reforms over the last three decades. As part of the Financial Sector Adjustment Programs (FINSAP I and II) implemented from the late 1980s through the mid1990s, Ghana's financial sector, then dominated by state-owned banks and the allocation and pricing of credit by government, was gradually liberalized. FINSAP I and II focused on restructuring of financially-distressed banks, improving regulatory and supervisory framework, and promoting non-bank financial institutions.

In the early 2000s, the Government developed the Financial Sector Strategic Plan I and II (FINSSP I \& II) to address the weaknesses in the financial sector. FINSSP I, was adopted in 2003 for implementation through 2008 and the FINSSP II was introduced to serve as the blueprint for Ghana's financial sector development which was implemented over a five-year period from $2012-2016$.

Financial Development is the costs of acquiring information, enforcing contracts, and making transactions create incentives for the emergence of particular types of financial contracts, markets and intermediaries. Different types and combinations of information, enforcement, and transaction costs in conjunction with different legal, regulatory, and tax systems have motivated distinct financial contracts, markets, and intermediaries across countries and throughout history.

Financial development occurs when financial instruments, markets, and intermediaries ameliorate though do not necessarily eliminate - the effects of information, enforcement, and transactions costs. Thus, financial development involves improvements in the (i) production of ex-ante information about possible investments, (ii) monitoring of investments and implementation of corporate governance, (iii) trading, diversification, and management of risk, (iv) mobilization and pooling of savings, and (v) exchange of goods and services. Each of these financial functions may influence savings and investment decisions and hence economic growth.

One of the debates in growth theory is the extent to which financial development leads to economic growth. It is not implausible to posit a positive correlation between growth in the financial and real sectors. However, the causal relationship is not clear. Which is the cause and which is the effect? Is finance the leading engine of economic development or does it simply follow growth from elsewhere? 
In view of the above, a motivation for this study was envisaged. Hence the topic "Financial Sector Development and economic Growth: The case of Ghana" where the study models relationship between economic growth and financial sector development for Ghana from the period 1980 to 2014 with the aim to studying the links between these two sectors.

In so far as economic growth performance and financial sector development are concerned in Ghana, there has been little empirical research done to investigate the direction of causality or to determine whether a relationship exists between economic growth and financial sector developments.

In the face of this research insufficiency in Ghana about the contributions of the financial sector to economic growth, this paper seeks to empirically establish whether financial development in Ghana for the period under consideration positively impacted economic growth and whether a long-run relationship exists between the two variables.

The study is very significant in the sense that it is one of the researches conducted on the subject matter and will provide greater incentive that could raise the confidence level for policy-makers in addressing reform needs, especially in the financial sector that is very much underdeveloped and now facing numerous issues of confidence crisis, adequate resource pooling and transferring in terms of loan availability investment projects whose purpose will be to enhance the growth process of an emerging nation.

This paper is organised into five sections with section one covering the introductory background of the study. Section two deals with the theoretical and emperical literature review. Section three focuses on the theoretical framework, methodology and model specification and data exploration techniques. Section four hinges on estimation and interpretation of empirical results while Section five covers summary, conclusions and policy recommendations.

\section{THEORETICAL AND EMPIRICAL LITERATURE REVIEW}

\subsection{Theoretical Literature}

Economists disagree sharply about the role of the financial sector in economic growth. Finance is not even discussed in a collection of essays by the "pioneers of development economics," which includes three winners of the Nobel Prize (Meier and Seers, 1984). Nobel Laureate Robert Lucas (1988) dismisses finance as a major determinant of economic growth calling its role "over-stressed." Joan Robinson (1952, p. 86) famously argued that "where enterprise leads finance follows." From this perspective, finance does not cause growth; finance responds automatically to changing demands from the "real sector." At the other extreme, Nobel Laureate Merton Miller (1988, p.14) argues that, "[the idea] that financial markets contribute to economic growth is a proposition too obvious for serious discussion." Similarly, Bagehot (1873), Schumpeter (1912), Gurley and Shaw (1955), Goldsmith (1969), and McKinnon (1973) have all rejected the idea that the finance- growth nexus can be safely ignored without substantially impeding our understanding of economic growth.

Resolving the debate and advancing our understanding about the role of financial factors in economic growth will help distinguish among competing theories of the process of economic growth. Furthermore, information on the importance of finance in the growth process will affect the intensity with which researchers study the determinants, consequences, and evolution of financial systems. Finally, a better understanding of the finance-growth nexus may influence public policy choices since legal, regulatory, tax, and macroeconomic policies all shape the operation of financial systems.

There are two possible causal relationships between financial development and economic growth. Patrick (1966) identified the two relationships as the 'demand following' and the 'supply leading'. The 'demand following' views demand for financial services as dependent upon the growth of real output and upon the commercialization and financial institutions, their financial assets and liabilities and related financial services are a response to the demand for these services by investors and savers in the economy. As real national income grows, there will be more demand by enterprise for external funds, and hence a need in the increase in the level of financial intermediation so as to transfer saving to fast growing industries from the slow-growing ones. By so doing the expansion of the financial system is indeed a consequence of real economic growth.

The supply leading causal relationship has two functions. These are, to transfer resources form traditional low-growth sector to the modern high-growth sectors and to promote and stimulate an entrepreneurial response in the modern sector (Patrick, 1966). This implies that the creation of financial institutions and their services occurs in advance of the demand for them.

\subsection{Empirical Literature}

Early empirical studies simply used a case study approach of relating cross-country growth rate with the level of financial development, e.g. IMF (1983) and McKinnon (1973). Others consist of just the examination of the direction of causation between economic growth and the level or growth of financial intermediation as in the case of studies reported by Jung (1986) and Odedokun (1992a), among others. Some others like Fritz (1984); Jao (1976); and Lanyi and Saracoglu (1983); adopted the approach of testing for the effects of financial 
intermediation variables (e.g. financial depth and the growth of real money balances) in the economic growth equations. Other recent empirical studies that were based on a similar approach include Gertlerand Rose (1991); Ghani (1992); King and Levine (1993a; 1993 c); Odedokun (1992b); and Roubini ad Sala-i- Martin (1991). Most of these studies have reported effects of financial intermediation on economic growth.

Empirical work on finance and growth assesses the impact of the operation of the financial system on economic growth, whether the impact is economically large, and whether certain components of the financial system, e.g., banks and stock markets, play a particularly important role in fostering growth at certain stages of economic development.

The literature reviewed demonstrated that financial sector development plays an important role in economic growth supporting the findings of Gockel, 1995 which posit that financial development is a necessary condition for economic development which was demonstrated by his discussion of the theoretical literature and the empirical experiences of Britain, Germany and France. Quite correctly, Ghana realized the pivotal role of financial development in economic growth and structural change and accordingly, steps were taken to establish financial institutions, of which the banking system was the most significant.

\section{THEORETICAL FRAMEWORK AND METHODOLOGY}

\subsection{Theoretical Framework}

The theoretical framework employed in this paper is patterned after an adaptation of the model used by Odedokun, which was developed by Feder (1983) for evaluating the impact of export expansion on economic growth. Basically, the basis of Odedokun's theoretical framework is a two-sector production, with the two sectors being the financial and non-financial (or real) ones. The output of the financial sector $(F)$ depends on the quantity of labour $\left(\mathrm{L}_{\mathrm{F}}\right)$ employed in this sector and the capital $\left(\mathrm{K}_{\mathrm{F}}\right)$ engaged, so that the production function in the sector can be seen below as:

$$
\mathrm{F}=\mathrm{F}\left(\mathrm{L}_{\mathrm{F}}, \mathrm{K}_{\mathrm{F}}\right)
$$

The output of the non-financial sector also depends on the quantities of labour $\left(\mathrm{L}_{R}\right)$ and capital $\left(\mathrm{K}_{\mathrm{R}}\right)$ engaged there.

In addition, because of the possibility of externalities or positive external effects that the output of the financial sector (i.e. financial intermediation) might have on the real sector, the real sectors' output can be described as a function of the financial sector's output so that the production function in the real sector is specified as equation 3.11 below:

$$
\mathrm{R}=\mathrm{R}\left(\mathrm{L}_{\mathrm{R}}, \mathrm{K}_{\mathrm{R}}, \mathrm{F}\right)
$$

Because only two sectors are recognized to exist, we have the relationships described below, where total output (Y) is made of output from the financial sector and non-financial sector totals as well as labour force (L) and total capital stock $(\mathrm{K})$ :

$$
\begin{aligned}
& \mathrm{Y}=\mathrm{F}+\mathrm{R} \\
& \mathrm{L}=\mathrm{L}_{\mathrm{F}}+\mathrm{L}_{\mathrm{R}} \\
& \mathrm{K}=\mathrm{K}_{\mathrm{F}}+\mathrm{K}_{\mathrm{R}}
\end{aligned}
$$

By permitting the marginal productivity of each of the two factors of production to differ between the financial and real sector in such a way that the inter-sectoral marginal productivity ratio of labour $\left(\mathrm{MPL}_{\mathrm{F}} / \mathrm{MPL}_{\mathrm{R}}\right)$ equals the inter-sectoral marginal productivity ratio of capital $\left(\mathrm{MPK}_{\mathrm{F}} / \mathrm{MPK}_{\mathrm{R}}\right)$, we have:

$\mathrm{MPL}_{\mathrm{F}} / \mathrm{MPL}_{\mathrm{R}}=\mathrm{MPK}_{\mathrm{F}} / \mathrm{MPK}_{\mathrm{R}}=1+\delta$

Where: $M P L_{F}=$ marginal productivity of labour in the financial sector;

$\mathrm{MPL}_{\mathrm{R}}=$ marginal productivity of labour in the real sector

$\mathrm{MPK}_{\mathrm{F}}=$ marginal productivity of capital in the financial sector;

$\mathrm{MPK}_{\mathrm{R}}=$ marginal productivity of capital in the real sector; and

$\delta=$ an indicator of the sector with higher marginal productivity.

It can be easily observed that if $\delta>0$, it is the financial sector where the marginal productivities of both factor inputs are higher, with the reverse being the case if $\delta<0$. A manipulation of the equations $3.12 \mathrm{a}, 3.12 \mathrm{~b}$, and $3.12 \mathrm{c}$ as done by Feder (1983), yields the aggregate output (or real GDP) growth equation thus:

or

$$
\mathrm{GY}=\lambda \mathrm{GK}+\beta \mathrm{GL}+[\delta /(1+\delta)-\theta] \mathrm{GF}(\mathrm{F} / \mathrm{Y})+\theta \mathrm{GF}
$$

$$
\mathrm{GY}=\alpha(\mathrm{I} / \mathrm{Y})+\beta \mathrm{GL}+[\delta /(1+\delta)-\theta] \mathrm{GF}(\mathrm{F} / \mathrm{Y})+\theta \mathrm{GF}
$$

Where the letter G before a variable indicates its growth rate so that GY, GL, GF, and GK are the growth rates of real GDP, labour force, financial sector's output and the real capital stock respectively while 1 is the investment or change in capital stock respectively while $\mathrm{I}$ is the investment or change in capital stock, $\Delta \mathrm{K}$. The definitions of other parameters in the equations are as follows:

$\alpha$ : the marginal productivity of capital in the non-financial sector, which

is denoted by $\mathrm{MPK}_{\mathrm{R}}$ in equation 3.12d above;

$\lambda$ : the elasticity of there all sector's output ( R) with respect to capital 
stock $(\mathrm{K})$;

$\beta$ : the elasticity of the real sector's output ( R) with respect to labour

force $(\mathrm{L})$;

$\theta$ : the elasticity of the real sector's output $(\mathrm{R})$ with respect to the

financial sector's output $(\mathrm{F})$ or

$\partial \mathrm{R} / \partial \mathrm{F}$ from equation 3.11 multiplied by $\mathrm{F} / \mathrm{R}$ ratio. (It should be noted that $\theta$ and $\partial \mathrm{R} / \partial \mathrm{F}$ are measures of the external effects of the increase in the financial sector's output on the rest of the economy or the real sector).

The two equations above are equivalent. The only exception being that while investment /GDP (I/Y) ratio features in the second equation so that I signifies the marginal productivity of capital stock, it is the growth rate of capital stock $(\mathrm{dK} / \mathrm{K}$ or $\mathrm{GK})$ which features in the first equation instead so that the $\lambda$ represents the elasticity of real GDP with respect to the capital stock. By assuming that $\theta$ is constant across the small observations, equation $3.13 \mathrm{a}$ can be rotationally simplified to the following (with the same being equally applicable to equation $3.13 \mathrm{~b}$ which we henceforth refrain form writing to any longer, for the sake of brevity):

$$
\mathrm{GY}=\lambda \mathrm{GK}+\beta \mathrm{GL}+\pi \mathrm{GF}(\mathrm{F} / \mathrm{Y})+\theta \mathrm{GF}
$$

Equation 3.14a is amenable to estimation, with estimates being separately provided for $\delta$ (or inter-sectoral factor productivity differential) and $\theta$ (a measure of the external effects of increase in financial intermediation on the real sector) is the inter-sectoralproductivity differential so that $\delta=0$, it can be seen that the coefficient of GF would be equal to that of GF $(\mathrm{F} / \mathrm{Y})$.

By setting value of $\pi$ in equation 3.14a to zero, we shall have a special case of this equation that can be written as:

$$
\mathrm{GY}=\lambda \mathrm{GK}+\beta \mathrm{GL}+\theta \mathrm{GF}
$$

Equation $3.14 \mathrm{~b}$ is the form that can easily be arrived at by simply introducing financial intermediation as an input in the aggregate production function, which would then take the form: $Y=Y(L, K, F$.$) .$

\subsection{Methodology}

The paper adopted both descriptive and empirical analytical approaches. A test for unit root or stationarity was conducted so as to establish the order of integration of the variables with the view to finding out whether there exists evidence of cointegration amongst the variables using the Johnansen and Juselius (1990) cointegration procedure where a determination of the existence of a long-run relationship between economic growth and financial sector development was established. The causal relationship (be it uni-directional or bi-directional) was examined with the help of the Granger-causality approach. Estimation of the model was done using cointegration and Error Correction Modeling (ECM) to check the availability of long run relationship among the variables to find out which of the variables was the most important determinant of economic growth.

\subsection{Model Specification}

The paper adopted a model (equation 3.15 below) based on a modification of the model used by Odedokun (1998) where he used two alternative measures of financial intermediation, the stock of domestic credit to the private sector and the stock of liquid liabilities while this study uses the stock of domestic credit to the private sector as a proxy to investigate the role of financial sector development on economic growth in Ghana (country specific).

The GDP growth equation estimated in this paper is seen below as:

$\mathrm{LnGDP}=\alpha_{0}+\alpha_{1} \operatorname{Ln} \mathrm{CPS}+\alpha_{2} \operatorname{LnK}+\alpha_{3} \operatorname{LnX}+\alpha_{4} \operatorname{LnL}+\varepsilon$

Where:

GDP stands for Gross Domestic Product,

LnGDP is the Growth Rate,

$\alpha_{0}, \alpha_{1}, \alpha_{2}, \alpha_{3}, \alpha_{4}$, are coefficients,

CPS is domestic credit to the private sector,

$\mathrm{K}$ is capital stock,

$\mathrm{L}$ being labor force

$\mathrm{X}$ represents exports,

$\varepsilon$ is the error term assumed to be Gaussian white noise and

Ln stands for natural logarithm.

\subsection{Data Exploration Techniques}

Time series data for the period 1980-2014 obtained from the world development indicators of the World Bank (http://databank.worldbank.org), was employed in this paper and OLS applied for estimation purposes. Both Stationarity and Cointegration tests, recent developments in time series econometrics, was applied in the estimation process. 


\section{ESTIMATION AND INTERPRETATION OF RESULTS}

\subsection{Stationarity Test}

In order to assess the stationarity of the variable used in the models, all the variables were transformed into natural logarithm and Augmented Dicky-Fuller test was performed on the variables. The test was performed under the assumption: 1) that the times series variables follow a given trend - that is Augmented Dicky-Fuller test with trend and 2) the vice versa - Augmented Dicky-Fuller without trend. The importance of this is to determine whether trend variable must be included in the final model for estimation or not. The results are shown in table 4.1 below.

Table 4.1: Augmented Dicky-Fuller Test at levels

\begin{tabular}{llllc}
\hline & \multicolumn{2}{c}{ Without trend } & \multicolumn{2}{c}{ With trend } \\
Variable & Test statistics & p-value & Test statistics & p-value \\
\hline LnGDP & 0.431 & 0.9826 & -1.443 & 0.8478 \\
LnCPS & 0.143 & 0.9689 & -2.734 & 0.2223 \\
LnX & -0.108 & 0.9486 & -2.669 & 0.2493 \\
LnL & -2.018 & 0.2788 & -0.889 & 0.9574 \\
LnK & -0.293 & 0.9264 & -2.466 & 0.3449 \\
\hline
\end{tabular}

Mackinnon approximate p-value: Without trend: $-3.689(1 \%),-2.975(5 \%)$, and $-2.619(10 \%)$

With Trend: $-4.297(1 \%),-3.564(5 \%)$, and $-3.218(10 \%)$

Source: Authors' estimation using Stata 13.0

As shown in Table 4.1, the test statics and the p-values indicates that all the variables were not stationary at level- that is they were not integrated at order zero [I(0)]. This means that there exist unit root among the variables. In order to use such variable to generate regression coefficient that are unbiased and efficient they must be made stationary. Consequently, the first difference of the real Gross Domestic Product (GDP), credit to the private sector (CPS), export of good and services (X) and physical capital formation (K) were taken and Augmented Dicky-Fuller test was performed on the variables. The results are shown in Table 4.2.

Table 4.2: Augmented Dicky-Fuller test at levels as first difference

\begin{tabular}{lllll}
\hline & \multicolumn{2}{c}{ Without trend } & \multicolumn{2}{c}{ With trend } \\
Variable & Test statistics & p-value & Test statistics & p-value \\
\hline LnGDP & -4.432 & 0.0003 & -4.439 & 0.0019 \\
LnCPS & -5.035 & 0.0000 & -4.917 & 0.0003 \\
LnX & -4.921 & 0.0000 & -4.742 & 0.0006 \\
LnL & -5.773 & 0.0000 & -6.417 & 0.0000 \\
LnK & -5.632 & 0.0000 & -5.468 & 0.0000 \\
\hline
\end{tabular}

Mackinnon approximate p-value: Without trend: $-3.696(1 \%),-2.978(5 \%)$, and $-2.620(10 \%)$

With Trend: $-4.306(1 \%),-3.568(5 \%)$, and $-3.221(10 \%)$

Source: Authors' estimation using Stata 13.0

As shown in table 4.2 the first different of GDP, CPS, $\mathrm{X}$ and $\mathrm{K}$ are all stationary. On the basis of this fact, the null hypothesis of non-stationary is rejected and we conclude that the variables are integrated in order one, i.e. [I (1)].

Theory posit that when two or more variables are integrated of order one then there might be a long run relationship between the variable which can be captured using error correction model (Engle and Granger, 1987). Granger causality test was performed to detect a causal relationship between economic growth and the explanatory variables (Granger, 1969). Cointegration test was performed to assess the possibility of a long run relationship between the variables. The results indicated one cointegrating relationship as indicated in Table 4.3.

\subsection{Cointegration Test}

Table 4.3 shows the results of the Johansen cointegration test. The coefficient is negative and statistically significant at one (1) percent. This indicates that there exist a long run relationship between economic growth and the explanatory variables.

Table 4.3: Cointergration test

\begin{tabular}{ccccccc}
\hline Variable & Coefficient & Std. Err. & $\mathrm{T}$ & $\mathrm{p}>|\mathrm{t}|$ & [95\% Conf. & Interval] \\
\hline RES & -4.797204 & 0.1479304 & -3.24 & 0.003 & -.7837957 & -.175645
\end{tabular}

It also gives credence to the use of error correction model in order to capture both long run and short run variations in economic growth and the explanatory variables under consideration. The result of the final economic growth model estimated in this study is presented in Table 4.4. 
4.3 Regression Results

Table 4.4: Regression Results

\begin{tabular}{|c|c|c|c|c|c|c|}
\hline Source & SS & Df & MS & & $\begin{array}{ll}\begin{array}{l}\text { Number } \\
\text { observations }\end{array} & \text { of }\end{array}$ & 34 \\
\hline & & & & & $\mathrm{F}(7, \quad 26)$ & 7.18 \\
\hline Model & 0.6473 & 7 & 0.0925 & & Prob. $>$ F & 0.0001 \\
\hline Residual & 0.3347 & 26 & 0.0129 & & R-squared & 0.6591 \\
\hline \multirow[t]{2}{*}{ Total } & 0.9820 & 33 & 0.0298 & & Adj. R-squared & 0.5674 \\
\hline & & & & & Root MSE & 0.1135 \\
\hline D.lnGDP & Coef. & Std. Err. & $\mathrm{T}$ & $P>|t|$ & [95\% Conf. & Interval] \\
\hline lnGDP_1 & 0.0315 & 0.0281 & 1.1200 & 0.2720 & -0.0262 & -0.0893 \\
\hline D.InCPS & 0.4447 & 0.0924 & 4.8100 & 0.0000 & 0.2546 & 0.6348 \\
\hline D. $\ln X$ & 0.0587 & 0.1071 & 0.5500 & 0.5890 & -0.1617 & 0.2790 \\
\hline D. $\ln L$ & -0.4457 & 1.0727 & -0.4200 & 0.6810 & -2.6507 & 1.7593 \\
\hline D. $\ln K$ & 0.2362 & 0.1062 & 2.2200 & 0.0350 & 0.0178 & 0.4547 \\
\hline D.GDPgr & 0.0009 & 0.0078 & 0.1300 & 0.9000 & -0.0151 & 0.0171 \\
\hline RES_1 & -0.4797 & 0.1479 & -3.2400 & 0.0030 & -0.7838 & -0.1756 \\
\hline cons & -0.2989 & 0.2667 & -1.1200 & 0.2730 & -0.8471 & 0.2493 \\
\hline
\end{tabular}

As shown in Table 4.4 the error correction term RES_1 is negative as expected and statistically significant at $1 \%$ because the $\mathrm{P}$-value is 0.003 . It indicate a fast rate of adjustment to the equilibrium.

Credit to the private sector (CPS) had a positive sign as expected and statistically significant at one(1) percent significant level. The result shows that a percentage increase of credit to the private sector will lead to 0.44 percentage increase in economic growth. This result is in line with a study conducted by Kamara (2007) on financial sector development and economic growth in Liberia.

Exports of good and service also had a positive sign as expected. The results indicate that a percentage increase in export leads to 0.05 percentage increase in economic growth. However, this is statistically insignificant at even 10 percent level.

Capital formation (Investment) also had a positive sign as expected. It shows that a percentage increase in capital formation $(\mathrm{K})$ will leads to 0.23 percentage increase in economic growth (GDP) and is statistically significant at $5 \%$ (the $\mathrm{P}$-value is 0.03 ) which is significant.

The results also indicate that labour force contribute negatively to economic growth. A percentage increase in labour force leads to -0.44 percent increase in economic growth, although this is not statistically significant.

The intercept has a negative sign which indicates that all other variables excluded in the model contribute negatively to economic growth; however, this is not statistically significant.

The R-squared value of 0.6591 shows that about 65.9 percent of the variations in economic growth are explained by the regressors in the model, when adjusted for degree of freedom this account for about 56.7 percent. The F-statistic of 7.18 with the associated p-values of 0.0001 indicates that all the variables included in the model together statistically significantly explain the variations in the dependent variable.

In all, the results reveal a positive relationship between financial development and economic growth in Ghana with the direction of causality predominantly running from financial development to economic growth.

\section{SUMMARY, CONCLUSIONS AND POLICY RECOMMENDATIONS}

The study found out that financial sector development, that is, credit to the private sector, and increases in exports, capital formation and use of labour force have positive effect on economic growth in Ghana. More specifically developments that increases credit to the private sector turn out to increased economic growth by 0.44 percent. This is statistically significant and represents the main thrust to enhance economic growth. The Granger causality test revealed a one-way causation between economic growth and financial sector developments with financial sector developments Granger causing economic growth. This results was affirmed by the coefficient of the lagged dependent variable which is positive, though, but statistically insignificant. The results also show that there exist a long run relationship between economic growth and financial sector development with a fast rate of adjustment to the equilibrium of about 0.47 percent.

In line with the above findings the study concludes that there exist a positive long run relationship between economic growth and financial sector development with financial sector developments Granger causing economic growth in Ghana. The enabling environment and financial sector interventions such as low interest rate that will enhance transfer of credit to the private sector must be pursued to enhance the economic development of Ghana.

Government should put in place appropriate fiscal and monetary policies to encourage the increase of 
credits to the private sector of the economy. This will boost economic growth immensely as shown by the results from our analysis.

Government should encourage domestic producers with favourable tax incentives to enable them produce more for export which will intend increase the country's GDP to a great extend as supported by the data analysis.

Government policy should focus on ensuring that capital stock is allocated efficiently to the productive sectors of the economy such as industry and agriculture. This should be done by factoring in the appropriate technology.

Policies should be put in place to increase and improve upon the human capital accumulation of skills in all areas, both financial and real sectors of the economy, to have a positive effect on the Ghanaian economy. Quality labour force adds to savings by investing in human capital.

Lack of a developed financial system restricts economic growth and therefore government policies should be directed towards encouraging the growth of the financial sector of the Ghanaian economy.

\section{FURTHER STUDIES}

It is recommended that further studies should be carried out on financial deepening to determine more variables that can stir up fast economic growth in Ghana. In addition, studies should be done on how financial inclusion can help reduce poverty which would have impact on the economic development of Ghana. We also recommend the employment of technology in further studies on financial sector development in Ghana.

\section{COMPETING INTERESTS}

We hereby declare that no competing interests exist.

\section{REFERENCES}

Akoena, S.K. (1996). "Demand for Money in Ghana: A Cointegration and Error Correction Approach and Comparison of Alternative Models." Unpublished Ph.D Thesis, University of Manitoba, Winnipeg, Canada.

Amusa, A. (2001). "The Impact of Financial Development on Economic Growth: The Case of South Africa.’University of Pretoria, South Africa. Unpublished.

Baomol. W.J (1986). "Productivity, Growth, Convergence and Welfare.What the Long Run Data Show", American Economic Review. Vol. 76 (5), pp. 1072-85.

Beck, T., A. Demirgue, and Ross Lenine (1999). A New Database on the Structure and Development of the Financial Sector, World Bank Economic Review, September, 14 (3), 597-605.

Bencivenga, V. and B.D. Smith (191). "Financial Intermediation and Endogenous Growth: The Review of Economic Studies, Vol. 58 (2), pp. 195-209.

Ben M'Rad, F. (2000). "Financial Development and Economic Growth: Time Series Evidence form South Mediterranean Countries." Universite Paris IX, Daupine.

Bermanke, B. S. and R.S Gurkaynak (2001). "Is Growth Exogenous? Taking Mankiw, Romer and Weill Seriously." NBER Working Paper No. 8365. Cambridge, Massachusetts: National Bureau of Economic Research.

De Gregorio, J. (1993). "Inflation, Taxation and Long-Run Growth", Journal of Monetary Economics, 31:271-98 and P.E. Guidotti (1995). "Financial Development and Economic Growth", World Development, vol. 23 (3), pp. 433-448.

Demetrides P.O. and Hussein K.A. (1996). "Does Financial Development Cause Economic Growth? Time Series Evidence from 16 countries", Journal of Development Economics, vol. 51:387-411.

Demirgue-Kunt, A. and M. Vojislav (1996). "Financial Constraints, Uses of Funds and Firm Growth: An Intermediation Comparison.” Working Paper, World Bank.

Dickey, D. and Fuller, W. (1979). "Distribution of the Estimators for Autoregressive Time Series with a Unit Root." Journal of the American Statistical Association, vol. 74, pp.427-31.

Engle, R.F. and Granger, C.WJ (1987). "Cointegration and Error Correction: Representation, Estimating and Testing." Econometrical, vol. 55, pp.251-76.

Feder, G. (1983). “On Export and Economic Growth.” Journal of Development Economics,vol. 35:59-73.

Financial Sector Reform Document (FINSSP I\& II): Ministry of Finance and Economic Planning, Ghana

Friedman, M. (1959). "The Demand for Money: Some Theoretical and Empirical Results" Journal of Political Economy, volume 76, pp. 327-51.

Fritz, R. G. (1984). "Time Series Evidence on the Causal Relationship between Financial Deepening and Economic Development", Journal of Economic Development, July, pp. 91-112.

Gross, D. M. (2001). "Financial Intermediation: A Contributing Factor to Economic Growth and Employment", International Labour Office, Working Paper Paper, pp. 1-29. 
Gujurati, D.N. (1995). Basic Econometrics. United States Military Academy, West Point, McGraw-Hill.

Gurley, J. and E. Shaw (1955). "Financial Aspects of Economic Development." American Economic Review, 45, 515-38.

Johansen, S. (1998). "Statistical Analysis of Cointegraion Vectors", Journal of Economic Dynamics and Control, Vol. 12:231-54.

and Juselius K. (1990). "Maximum Likelihood Estimation and Inference on Cointegraion with Application to the Demand for Money", Oxford Bulletin of Economics and Statistics, vol. 52, pp.169210.

Johnson, H.G (1969). "Inside Money, Outside Money, Income, Wealth and Welfare in Monetary Theory", Journal of Money, Credit and Banking, Vol. 1, pp. 30-45.

King, R. and Levine, R. (1993a). "Financial Entrepreneurship and Growth: Theory and Evidence", Journal of Moentary Economics, Vol. 32 (3), pp. 513-542.

(1993b). "Financial Intermediation and Economic Development" Mayer, C. and Vives, X. (Eds), Capital Markets and Financial Intermediation, Center for Economic Policy Research, London.

_ _ (1993c). "Finance and Growth: Schumpeter Might Be Right", Quartely Journal of Economics, Vol. $108(3)$, pp.717-37.

Levine, R. (1997). "Financial Development and Economic Growth: Views an Agenda", Journal of Economic Literature, Vol.35 (2), pp. 688-726.

, Loayza, N. and Beck, T. (2000). "Financial Intermediation and Growth: Causality and Causes”, Journal of Monetary Economics, Vol. 46 (1): 31-71.

McKinnon, R. L. (1973). Money and Capital in Economic Development, The Brookings Institutions, Washington, D.C..

Montiel, P.J. (1997). "Financial Policies and Economic Growth: Theory, Evidence and Country-Specific from sub-Saharan Africa."Journal of African Economics, Vol. 5 (3).

Odedokun, M. O (1998). "Financial Intermediation and Economic Growth in Developing Countries", Journal of Economic Studies, Vol. 25 (3), pp.203-224.

, (1992a). "Supply-Leading and Demand- Following relationship between economic activities and development banking in Developing Countries: An International Evidence", Singapore Economic Review, April, pp. 46-58.

, (1992b). "Multi-Country Evidence on the Effects of Macroeconomic, Financial and Trade Polices on Efficiency of Resource Utilization in Developing Countries." IMF Working Paper WP/92/53, Washington, D.C..

Patrick, H.T. (1966). "Financial Development and Economic Growth in Underdeveloped Countries." Economic Development and Cultural Change, Vol. 14 (2): 174-89. Quarterly, P. (1997).

Quartey, P. (1997). "Financial Sector Development, Savings Mobilization and Poverty Reduction in Ghana," ISSER, University of Ghana Research Paper No. 2005/71.

Rebelo, S. (1991). "Long-Run Policy Analysis and Long-Run Growth.” Journal of Political Economy, vol. 99, pp. 500-21.

Schumpeter, J.A (1912). "The Theory of Economic Development." Cambridge, MA: Harvard University Press.

Shaw, E.S. (1973). "Financial Deepening in Economic Development". New York, Oxford University Press.

Sjöö (1997). “An Introduction to Unit-Root Tests”, Discussion Paper, JFE Nairobi.

, (1997). "Non-Stationary and Cointegration-An Introduction", Discussion Paper, JFE Nairobi.

Stiglitz, J. and Weiss, A. (1981). "Credit Rationing in Markets with Imperfect Information." American Economic Review, Vol. 71 (3), pp. 393-410.

Waqabaca, C. (2004). "Financial Development and Economic Growth in Fiji." Working Paper/03, December 2004, Economics Department, Reserve Bank of Fijii.

World Bank, (1989). World Development report, Oxford University Press.

www.gipcghana.com

www.bog.gov.gh

www.databank.worldbank.org 


\begin{tabular}{|c|c|c|c|c|c|}
\hline \multicolumn{6}{|c|}{$\begin{array}{c}\text { APPENDIX } 1 \\
\text { SOME MACROECONOMIC INDICATORS }\end{array}$} \\
\hline Year & $\begin{array}{c}\text { GDP } \\
\text { (in ML\$) }\end{array}$ & $\begin{array}{l}\text { Credit to the } \\
\text { Private Sector } \\
\text { (in ML\$) }\end{array}$ & $\begin{array}{l}\text { Export } \\
\text { (in ML\$) }\end{array}$ & $\begin{array}{l}\text { Labour Force } \\
\text { (in Thousands) }\end{array}$ & $\begin{array}{c}\text { Gross Capital } \\
\text { Formation (in } \\
\text { ML\$) }\end{array}$ \\
\hline 1980 & $4,445.23$ & 97.35 & 376.35 & $4,241.49$ & 271.06 \\
\hline 1981 & $4,222.44$ & 78.12 & 200.81 & $4,382.98$ & 199.42 \\
\hline 1982 & $4,035.99$ & 72.65 & 134.73 & $4,554.96$ & 142.53 \\
\hline 1983 & $4,057.28$ & 62.48 & 225.42 & $4,744.18$ & 152.60 \\
\hline 1984 & $4,412.28$ & 97.51 & 354.92 & $4,912.14$ & 302.37 \\
\hline 1985 & $4,504.34$ & 140.08 & 479.91 & $5,090.62$ & 429.24 \\
\hline 1986 & $5,727.60$ & 207.91 & 949.41 & $5,256.44$ & 532.41 \\
\hline 1987 & $5,074.83$ & 159.86 & 997.84 & $5,426.75$ & 525.77 \\
\hline 1988 & $5,195.04$ & 163.12 & 994.64 & $5,597.88$ & 583.90 \\
\hline 1989 & $5,248.94$ & 306.53 & 878.81 & $5,775.33$ & 690.56 \\
\hline 1990 & $5,886.00$ & 290.18 & 993.43 & $5,962.96$ & 846.77 \\
\hline 1991 & $6,599.58$ & 241.54 & $1,119.52$ & $6,170.25$ & $1,044.28$ \\
\hline 1992 & $6,412.63$ & 316.78 & $1,104.63$ & $6,378.38$ & 816.71 \\
\hline 1993 & $5,965.70$ & 288.74 & $1,208.29$ & $6,630.76$ & $1,418.98$ \\
\hline 1994 & $5,440.52$ & 285.63 & $1,374.20$ & $6,890.06$ & $1,228.17$ \\
\hline 1995 & $6,457.44$ & 327.39 & $1,581.84$ & $7,154.24$ & $1,364.51$ \\
\hline 1996 & $6,925.53$ & 416.22 & $2,223.94$ & $7,422.62$ & $1,405.79$ \\
\hline 1997 & $6,884.02$ & 564.49 & $2,231.13$ & $7,695.83$ & $1,640.84$ \\
\hline 1998 & $7,474.02$ & 699.57 & $2,531.55$ & $7,974.69$ & $1,671.46$ \\
\hline 1999 & $7,709.81$ & 968.35 & $2,473.18$ & $8,260.52$ & $1,578.00$ \\
\hline 2000 & $4,977.49$ & 695.36 & $2,429.13$ & $8,554.24$ & $1,149.71$ \\
\hline 2001 & $5,309.16$ & 629.14 & 2401.49 & $8,808.94$ & $1,440.00$ \\
\hline 2002 & $6,159.57$ & 742.23 & $2,624.98$ & $9,068.52$ & $1,156.46$ \\
\hline 2003 & $7,624.16$ & 902.70 & $3,101.44$ & $9,331.80$ & 1748.75 \\
\hline 2004 & $8,871.87$ & $1,160.44$ & $3,486.94$ & $9,585.05$ & $2,517.62$ \\
\hline 2005 & $10,720.35$ & $1,665.94$ & 3907.48 & $9,852.13$ & $3,109.13$ \\
\hline 2006 & $20,388.32$ & $3,625.04$ & $5,136.37$ & $10,120.32$ & $4,411.16$ \\
\hline 2007 & $24,632.48$ & $4,379.65$ & $6,041.12$ & $10,376.03$ & $4,953.02$ \\
\hline 2008 & $28,526.92$ & $5,072.08$ & $7,140.13$ & $10,647.45$ & $6,119.68$ \\
\hline 2009 & $26,169.34$ & $4,652.90$ & $7,982.09$ & $9,767.50$ & $5,122.23$ \\
\hline 2010 & $32,174.77$ & $4,922.73$ & $9,484.06$ & $10,204.95$ & $8,364.12$ \\
\hline 2011 & $39,566.29$ & $5,974.50$ & $14,614.44$ & $10,492.13$ & $10,461.36$ \\
\hline 2012 & $41,939.72$ & $6,542.59$ & $16,926.54$ & $10,789.00$ & $13,330.43$ \\
\hline 2013 & $47,805.06$ & $8,174.66$ & $16,344.11$ & $11,068.84$ & $13,257.36$ \\
\hline 2014 & $38,616.53$ & $7,684.68$ & $15,262.62$ & $11,372.10$ & $10,480.28$ \\
\hline
\end{tabular}

Source: Compiled from World Development Indicators (WDI) and Global Development Finance (GDF) of the World Bank Data Bank (http://databank.worldbank.org) 


\section{APPENDIX 2}

PROCESSED DATA FOR REGRESSION ANALYSIS

\begin{tabular}{|c|c|c|c|c|c|c|}
\hline Year & $\operatorname{lnGDP}$ & $\operatorname{lnCPS}$ & $\operatorname{LnX}$ & $\ln L$ & $\ln K$ & GDPgr \\
\hline 1980 & 8.399587 & 4.578313 & 5.930520 & 8.352670 & 5.602340 & 0.471696 \\
\hline 1981 & 8.348168 & 4.358246 & 5.302359 & 8.385484 & 5.295413 & -3.503067 \\
\hline 1982 & 8.303007 & 4.285653 & 4.903273 & 8.423972 & 4.959553 & -6.923650 \\
\hline 1983 & 8.308268 & 4.134847 & 5.417965 & 8.464674 & 5.027820 & -4.563738 \\
\hline 1984 & 8.392147 & 4.579955 & 5.871892 & 8.499465 & 5.711651 & 8.647569 \\
\hline 1985 & 8.412797 & 4.942214 & 6.173599 & 8.535155 & 6.062016 & 5.091617 \\
\hline 1986 & 8.653052 & 5.337105 & 6.855841 & 8.567209 & 6.277414 & 5.199161 \\
\hline 1987 & 8.532048 & 5.074298 & 6.905593 & 8.599096 & 6.264864 & 4.794899 \\
\hline 1988 & 8.555460 & 5.094486 & 6.902381 & 8.630143 & 6.36973 & 5.628169 \\
\hline 1989 & 8.565781 & 5.725316 & 6.778569 & 8.661351 & 6.537503 & 5.085873 \\
\hline 1990 & 8.680332 & 5.670501 & 6.901164 & 8.693322 & 6.741429 & 3.328818 \\
\hline 1991 & 8.794761 & 5.487035 & 7.020655 & 8.727495 & 6.951083 & 5.281826 \\
\hline 1992 & 8.766025 & 5.758208 & 7.007266 & 8.760669 & 6.705284 & 3.879419 \\
\hline 1993 & 8.693782 & 5.665527 & 7.096961 & 8.799475 & 7.257694 & 4.850001 \\
\hline 1994 & 8.601630 & 5.654697 & 7.225627 & 8.837835 & 7.113281 & 3.300000 \\
\hline 1995 & 8.772988 & 5.791152 & 7.366344 & 8.875460 & 7.218551 & 4.112419 \\
\hline 1996 & 8.842970 & 6.031214 & 7.707036 & 8.912287 & 7.248355 & 4.602461 \\
\hline 1997 & 8.836958 & 6.335923 & 7.710263 & 8.948434 & 7.402964 & 4.196358 \\
\hline 1998 & 8.919188 & 6.550466 & 7.836587 & 8.984028 & 7.421453 & 4.700391 \\
\hline 1999 & 8.950249 & 6.875594 & 7.813260 & 9.019243 & 7.363914 & 4.399997 \\
\hline 2000 & 8.512681 & 6.544430 & 7.795288 & 9.054182 & 7.047265 & 3.700000 \\
\hline 2001 & 8.577189 & 6.444354 & 7.783845 & 9.083522 & 7.272398 & 4.000000 \\
\hline 2002 & 8.725762 & 6.609659 & 7.872829 & 9.112564 & 7.053119 & 4.500000 \\
\hline 2003 & 8.939077 & 6.805390 & 8.039622 & 9.141183 & 7.466657 & 5.200000 \\
\hline 2004 & 9.090641 & 7.056555 & 8.156780 & 9.167960 & 7.831069 & 5.600000 \\
\hline 2005 & 9.279899 & 7.418145 & 8.270648 & 9.195443 & 8.042098 & 5.900004 \\
\hline 2006 & 9.922717 & 8.195621 & 8.544102 & 9.222301 & 8.391893 & 6.399912 \\
\hline 2007 & 10.11182 & 8.384724 & 8.706345 & 9.247254 & 8.507753 & 4.346819 \\
\hline 2008 & 10.25860 & 8.531506 & 8.873486 & 9.273076 & 8.719265 & 9.149799 \\
\hline 2009 & 10.17234 & 8.445246 & 8.984956 & 9.186816 & 8.541345 & 4.845756 \\
\hline 2010 & 10.37894 & 8.501619 & 9.157368 & 9.230628 & 9.031706 & 7.899740 \\
\hline 2011 & 10.58573 & 8.695256 & 9.589765 & 9.258381 & 9.255444 & 14.046003 \\
\hline 2012 & 10.64399 & 8.786088 & 9.736638 & 9.286282 & 9.497805 & 9.292512 \\
\hline 2013 & 10.77489 & 9.008794 & 9.701623 & 9.311889 & 9.492308 & 7.312525 \\
\hline 2014 & 10.56144 & 8.946984 & 9.633162 & 9.338918 & 9.257251 & 3.985866 \\
\hline
\end{tabular}


APPENDIX 3

GRAPHICAL REPRESENTATIONS OF SOME MACROECONOMIC INDICATORS
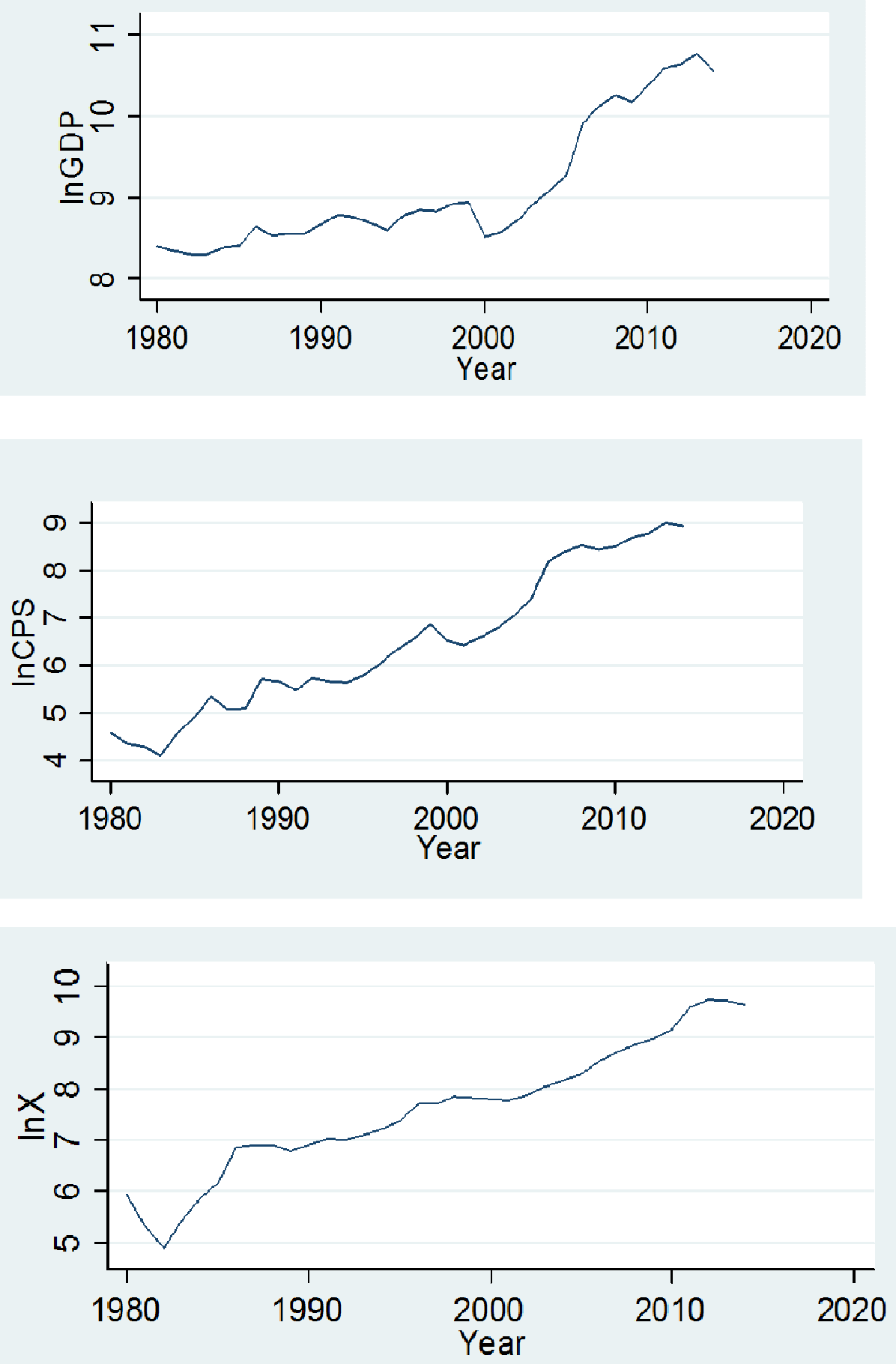

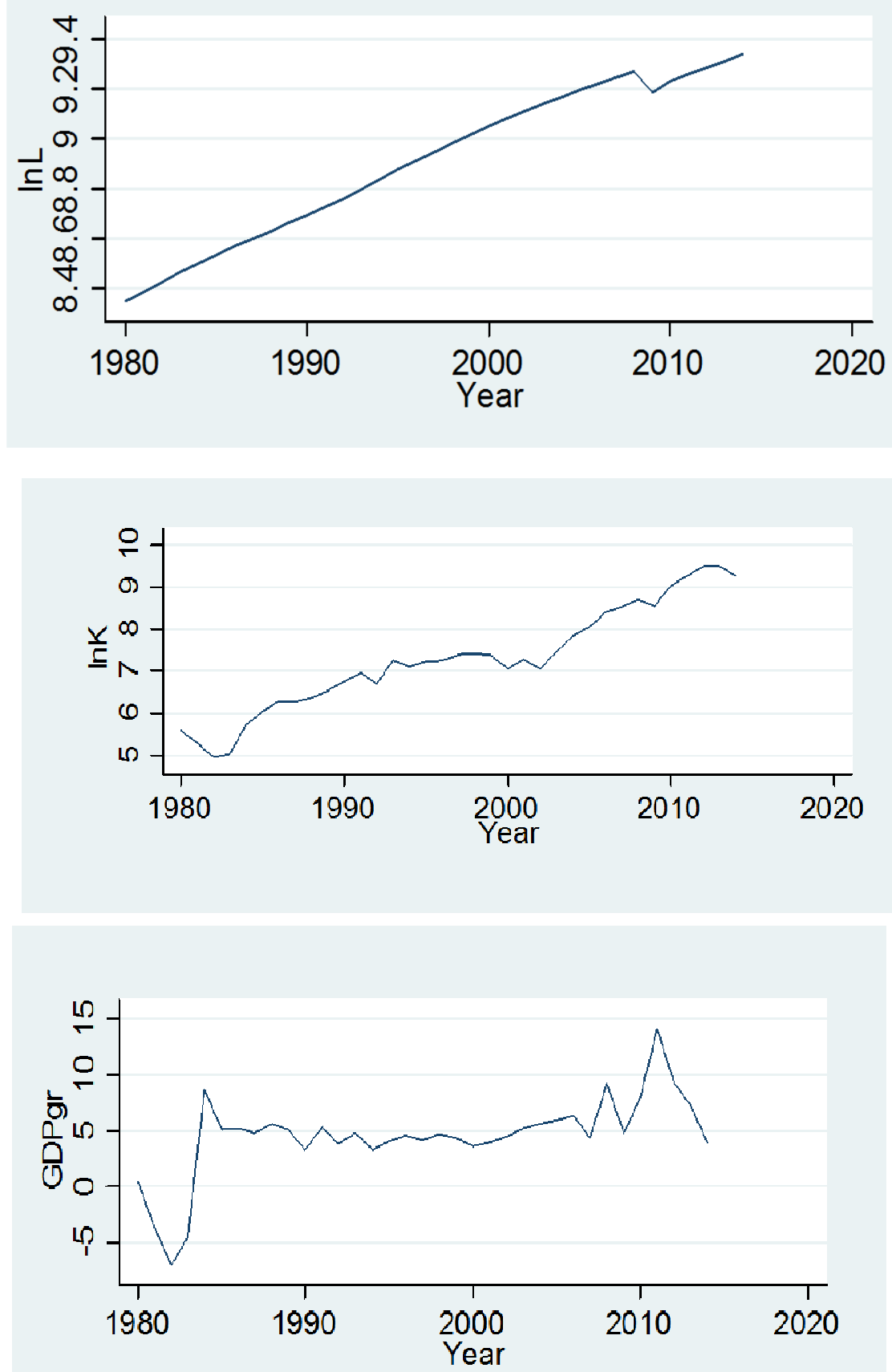